\section{Proteine im Urin}

W. G. Guder

München, Deutschland

Synonym(e) Urineiweiß; Gesamteiweiß im Urin

Englischer Begriff urine proteins; proteinuria; single proteins in urine; proteomics in urine

Definition Summe aller Proteine im Urin $(\triangleright$ Protein, gesamt im Urin).

Beschreibung Die Proteinurie stellt eines der Leitsymptome von Nierenerkrankungen dar. Neben der Bestimmung des
Gesamtproteins werden zunehmend differenzierte Bestimmungen verschiedener Proteine diagnostisch bedeutend, um differenzialdiagnostische, prognostische und therapeutische Aussagen und Entscheidungen zu unterstützen. Die $>$ Proteinuriediagnostik stellt die Leitlinie der modernen Proteinanalytik in der laboratoriumsmedizinischen Diagnostik dar.

\section{Literatur}

Guder WG, Boesken WH (2009) Gesamteiweiß im Urin. In: Guder WG, Nolte J (Hrsg) Das Laborbuch für Klinik und Praxis, 2. Aufl. Elsevier/Urban und Fischer, München, S 776-777

Hofmann W, Ehrich JHH, Guder WG, Keller F, Scherberich JE (2011) Diagnostische Pfade bei Nierenerkrankungen. Nieren- und Hochdruckkrankheiten 40:47-79 